Behavior and Social Issues, 19, 179-180 (2010). (C) Peter Lamal. Readers of this article may copy it without the copyright owner's permission, if the author and publisher are acknowledged in the copy and the copy is used for educational, not-for-profit purposes.

\title{
A Primer About B.F. Skinner ANd the Origins of Behavior ANALYSIS: BURRHUS F. SKINNER: THE SHAPING OF BEHAVIOUR. BY FREDERICK TOATES
}

(2009). New York: Palgrave Macmillan. ISBN 13-979-0-230-21866-6. 204 pp. $\$ 19.95$.

At the outset Toates recognizes that we might wonder whether there can be anything more to say about B.F. Skinner. Toates believes there is. This book is his attempt to integrate Skinner into mainstream psychology by describing where bridges can be built between the "Skinnerian perspective" and current cognitive, social, and biological perspectives. Toates outlines and later gives examples of a compromise between Skinner and the above-mentioned perspectives. He says there are three possibilities. One is the blanket rejection of Skinner. A second is complete acceptance of Skinner's work. A third is compromise, Toates' position. He argues that "Skinner accurately described some fundamental and often grossly underestimated and misunderstood determinants of human behavior" (p.19). But these determinants need to be integrated with other processes in order to have a more complete account of humans. One consequence of this integration would be replacement of the behavioral rejection of individuals' autonomy with a limited autonomy.

After a brief biographical sketch, including highlights of Skinner's early and later development of radical behaviorism, Toates considers evidence relating to Skinner's views. This includes consideration of the nature, effects of, and some issues regarding reinforcement.

Chapter Four compares Skinner's perspective with three other major perspectives with which Skinner has often been compared: the cognitive, Freudian, and humanistic schools. The conclusion is that reconciliation of Skinner is possible in some cases (e.g., with the cognitive school) but not others (e.g. the assumption of some degree of individuals' autonomy in the humanistic school). Also, with respect to biology the picture is mixed. Toates says that Skinner's view regarding biology was ambivalent. He never argued that the brain is unimportant but rather that an "understanding of behavior in its own right was necessary before one could understand the brain" (p. 87).

In a chapter devoted to determinism, freedom, and autonomy, Toates discusses three of the fundamental assumptions Skinner came to incorporate. These are: (a) behavior is the product of genes and environment; (b) psychology should eschew internal cognitive terms, instead should focus on the external 
environment; and (c) the idea of free will is a hindrance to the progress of behavioral science.

Chapters 7-12 describe the application of Skinner's ideas to solving problems in the areas of education, criminology, mental health, interpersonal relations and climate change.

In his concluding chapter Toates lists some general conclusions about the influence of Skinner. Examples: Skinner put the principle of reinforcement on a scientific footing and made clear its parameters. He presented a vision of how we might build an ecologically sound society, thus providing us a framework for having psychology impact the issue of climate change. Toates also revisits his call for compromise proposed at the outset.

Before reading this book, I thought "What, more about Skinner? What more is there to say?" But as he noted at the outset, Toates addresses such a reaction.

An irritant throughout the book is Toates' use of "Skinnerian" and the "Skinnerian perspective" rather than behavior analysis and behavior analysts. I suspect that other behavior analysts would also find this irritating. On the plus side the book includes references to a large number of relevant books and articles. One of them is Bjork's excellent biography of Skinner, for which Toates' book could serve as a companion. Also relevant is Rutherford's thesis.

Peter Lamal

\section{References}

Bjork, D.W. (1993). B.F. Skinner: A life. New York: Basic Books.

Rutherford, A. (2009). Beyond the box: B.F. Skinner's technology of behavior from laboratory to life, 1950s-1970s. Toronto: University of Toronto Press.

Skinner, B.F. (1976). Particulars of my life: Part 1 of an autobiography. New York: Knopf.

Skinner, B.F. (1979). The shaping of a behaviorist: Part 2 of an autobiography. New York: Knopf. Skinner, B.F. (1983). A matter of consequences: Part 3 of an autobiography. New York: Knopf.

Peter Lamal is a Fellow of the Division of Behavior Analysis of the American Psychological Association, and is a member of the Association for Behavior Analysis International. His book reviews have been published in academic journals, The Charlotte Observer newspaper and Skeptical Inquirer and The Humanist magazines. 